\title{
African literacies: Which of them matter, and why?
}

\author{
KATE PARRY Hunter College, City University of New York
}

\begin{abstract}
This paper draws on data collected at the Kitengesa Community Library in Masaka District of Uganda to discuss some of the different literacies that are important in African environments. First, the literacies associated with different languages are analysed, these being classified as supralanguages (English in Uganda), lingua francas (such as Kiswahili), and local languages (Luganda in Kitengesa). Literacies also vary with social context, and the paper considers the cases of school, family, peer group, and private literacies. Work at Kitengesa has shown that although literacy is generally thought of as part of school life, other literacies are developing in response to the opportunities provided by the library. Supralanguage and school literacies remain dominant, but it is argued that they will become much more productive if supported by other literacies and that it is a major function of a community library to help such other literacies to develop.
\end{abstract}

The plural use of the word literacy is quite recent, and the Oxford English Dictionary has not caught up with it. The dictionary's entry for the word is, in fact, a good summary of traditional attitudes:

Literacy: The quality or state of being literate; knowledge of letters; condition in respect to education, esp. ability to read and write. Also transf.

1883 New Eng. Jrnl. Educ. XVII. 54: "Massachusetts is the first state in the Union in literacy in its native population". $1888 \mathrm{New}$ Princeton Rev. Dec. 336: "Education is more general, our literacy greatly increased, our habits and tastes more refined". 1893: Athenoum 19 Aug. 255/3: "It was for Mr. Edgar to trace the gradual progress in Scotland from illiteracy to literacy".

The definition presents literacy as a unitary ability or condition that is characteristic of human beings as individuals, while the quotations show clearly the strong association between literacy, education, and progress. Since the 1980s, however, scholars have increasingly questioned these assumptions, and in working towards a richer understanding have regularly used the noun in the plural in order to emphasise the diversity of communicative practices that it 
names. An early and important advocate of this usage was Brian Street, who, in Literacy in Theory and Practice, pointed out that "Comparative material ... demonstrates that ... practices and conceptions [related to literacy] are very different from one culture to another" (Street, 1984: 2), and he therefore suggested, "we would probably more appropriately refer to 'literacies' than to any single "literacy"' (1984: 8). In the twenty-odd years since Street developed this idea, scholars have had a field day with literacies, a more recent example being the book Multiliteracies, which represents the thinking of a gathering of American and Australian scholars known as the New London Group. They emphasise not only the "increasing salience of ethnic and linguistic diversity" but also the "multiplicities of communications channels and media" (Cope and Kalantzis, 2000: 5); thus they talk about literacies in many different communicative modes-in visual images and specialised kinds of talk, as well as in various forms of script. In this paper I will not go so far, preferring to define a literacy as 'a use of language in written form'. I do so because written language-whether on paper or on screen-is of increasing rather than decreasing importance in most parts of the world, and that if literacy is used, without a qualifier, for communication that does not involve written text, we will have to invent another term for communication that does. On the other hand, I support strongly the notion of plural literacies, especially in the multilingual and multicultural contexts of Africa.

To illustrate my argument I will refer to a single literacy project, the Kitengesa Community Library, located near the trading centre of Kitengesa in Masaka District in the Central Region of Uganda. My husband and I have a home near Kitengesa, and there in 1997, I met Mawanda Emmanuel, the director and headmaster of a local secondary school, who told me that he wished to set up a community library. I decided to work with him on the project, so we began in 1999 with a box containing 160 books, which was all I could afford at the time. Seven years later, when this paper was first written, that box had grown into a building and the collection to more than 2,700 books; the building had solar electricity, which gave it light at night and ran two computers, and the library had well over 500 members.

The main purpose of the project was and is to serve the people who live around Kitengesa, including the students and teachers in Mawanda's school, but it also provides a means of documenting the literacy practices that develop in an African community that has long been interested in education but has hitherto had little access to books. Accordingly, we have since the beginning kept careful records of our stock and of how it is used. Over the first year we asked the students who borrowed the books to write a report on each one, saying who they had read or lent it to and how they and others had reacted to it. Later we instituted a book for people to sign when they came into the 
library, in which we asked them to indicate their reason for coming. Finally, every loan of a book is recorded, and the librarians keep track of which among the books that we do not lend appear to be the most used. This information is the basis of my discussion of literacies, though I believe that the points I make apply well beyond Kitengesa.

Given this journal's focus on Africa, the idea of multiple literacies should not be strange, for we all know that on this continent linguistic multiplicity is the norm (Mazrui and Mazrui, 1998, Parry, 2009, Rubagumya, 2009). As I have put it in a previous article, it is usual in Africa to grow up within a three-tiered system consisting of a single supralanguage, one or more lingua francas, and any number of local languages (Parry, 1999). The supralanguage-English, French, or Portuguese-is an inheritance of colonial rule and is used for central government and for the higher levels of education, if not throughout the system. The lingua francas-the best known of which are Kiswahili in East Africa and Hausa in West, but there are many others-are usually African languages that were spread through precolonial patterns of trade; they are used for general communication across ethnic groups, and, though they have a place in most education systems, tend to be learned informally. Many of them also function as local languages for subsets of their speakers. The local languages are associated with particular ethnic groups and many have rather few speakers; but they inspire deep loyalties, giving the term mother tongue, in the sense of the language that a child learns first, great emotive force. For each of these languages, I would argue, there is, at least potentially, a corresponding literacy, and each of these literacies is important, though for different reasons and in different ways.

For most Africans there is little argument that supralanguage literacy matters-even the humblest peasants in adult literacy programmes in Uganda express a desire to learn English (Carr-Hill et al., 2001: 90), and many of the users of the Kitengesa Library value it precisely because it provides access to English books (Dent and Yannotta, 2005). In focusing on English, these people are showing a good understanding of what has been called the ecology of literacy (Barton, 1994): English not only has a long and extensive tradition of writing (as do French and Portuguese as well), but it also dominates the education system, being taught in most cases from the beginning of primary school and being the medium of instruction throughout the secondary if not the primary level (Mazrui, 2004, Schmied, 1991). Also, through the system of educational certification, the supralanguage controls access both to jobs in the modern sector and to political power. In Uganda, for instance, candidates for political posts have to demonstrate that they have attained specified levels of education before they can stand for election and those levels cannot be attained without a good command of English. 
But the dependence of most African countries on supralanguage literacy raises serious matters to consider. First, there are political issues: many African writers, though superbly proficient in the supralanguage themselves, have questioned whether it is an appropriate medium for the conduct of national life and still more for the education of the nation's children. Their objections are, first, that the supralanguage is foreign, and, second, that it is associated with colonial rule; thus, to continue to use it is to accept continued "colonisation of the mind" (Ngugi wa Thiongo, 1986). For less literary minded people the problem is more practical: the supralanguage is simply so hard to learn. English and French, in particular, have more than usually difficult writing systems; it surely does not make sense to ask people to learn initial reading in these languages if there are other choices available. Then, even once the learner has "cracked the code" of the system (Downing, 1979), the language remains foreign, and in rural environments, especially, there is little support for what is learnt in class. Compounding these problems is the fact that most supralanguage materials also represent a culture that is foreign, and linguistic and cultural difficulties combined can create extraordinary difficulties of interpretation (Baleeta, 2004, Parry 1994, 2005). Pedagogical matters, then, are of great concern in supralanguage literacy: all too often the task of teaching and learning in the supralanguage proves too difficult and teachers resort to teaching, and students to learning, by rote (Rubagumya, 2009: 50-51).

The provision of appropriate materials is another, closely related matter, and here is where our evidence from Kitengesa comes into play. Most of the members of the library are students at Kitengesa Comprehensive Secondary School, and as secondary school students they have seven years of primary education behind them. It is interesting to note, then, how simple the material is that these students choose to take out and read: the most popular book in 20042005 was a title called Magulu and the Gorilla, the opening of which runs like this:

There once lived a man called Magulu. He was a hunter. One day Magulu went to hunt in an open grassland. The place was far away from his home. He went to hunt with all his six dogs. As Magulu was hunting, the clouds gathered. Soon it started to rain. And the rain became a storm. Magulu looked around for shelter. Then he saw a hut in the distance. Smoke was coming from the hut. Magulu went to the hut. He entered the hut with all his six dogs. Inside the hut, Magulu found a very beautiful woman ... (Matovu, 1994:1)

This book is written for primary school children, but it is at this level of language that these secondary school students are comfortable reading. The point 
is even more important for people who have dropped out of school at primary level, of whom there are many around Kitengesa. One of them spoke forcefully about the frustration of seeing many beautiful books, all of which were too difficult to understand.

The difficulty of understanding is partly a matter of language, obviously-especially one of vocabulary - but it is also one of culture. Magulu and the Gorilla is a traditional African folktale translated into English, and this genre has fairly consistently proved the most popular one in the library. Second most popular is a category that we call "Modern Stories", that is, stories set in modern Africa, featuring African characters. Third in popularity, though falling well behind the story books, are books categorised as "Health" and "Morals", both of which categories include material on sex education and emotional health; but serious as these topics are (and the students take them extremely seriously, for Masaka District has had plenty of experience with HIV/AIDS), the books are put into contexts familiar to African students and are written in simple English. All this means that even for English language books the library cannot and must not depend on donations from abroad; for donated books are far more foreign and are usually in language that is too difficult.

To many people, the fact that lingua franca literacy matters is somewhat less obvious. Yet the most widely used African lingua francas-Kiswahili and Hausa-have long traditions of literacy as well as being spoken by millions of people. They enable communication across extensive regions and among wide ranges of ethnic groups, and literacy in them gives access to valuable historical information. Most important, they are indigenous African languages and are spoken by ordinary people; unlike the supralanguages, they have never been confined to an educated (and westernised) elite (Mazrui and Mazrui, 1998: 77). Similarly, the lingua francas present less serious pedagogical problems than the supralanguages do; there is more support for them in the environment, their literatures and vocabulary are culturally accessible, and the writing system is in every case much more transparent than it is for English or French. The argument for using lingua francas in African education systems seems unanswerable, and, indeed, they figure prominently in official education policies. In Uganda, for instance, the Education White Paper of 1992 (which is still the basis for national education policy) stipulated that Kiswahili should be a compulsory subject in primary school and should be increasingly emphasised (Uganda Government, 1992: 17-22).

This is not to say that there are no pedagogical problems with regard to the lingua francas. They are, by definition, second languages for most of their speakers and have sound patterns and grammatical rules that are different from those of the speakers' first languages. Hausa, for example, has grammatical gender, 
a feature that presents difficulties for many of those who use it as a lingua franca; and since the language is largely learnt informally, the difficulties are typically not addressed, so that, for example, the gender distinctions are simply ignored by those who speak Hausa along the border between Nigeria and Cameroun. Since in printed Hausa these distinctions are always maintained, a conflict is created between what is heard in the environment and what is read in the books. Educators, then, have to decide how insistent on "correct" usage, according to native speaker norms, they should be with regard to students' writing. A high degree of insistence loses some of the advantages of accessibility and environmental support that the lingua franca has; but a more casual attitude might well be interpreted as a suggestion that lingua franca literacy does not matter so much after all-especially if, as is the case at present, there is strong pressure for grammatical accuracy in written use of the supralanguage.

Another matter of concern is the nature of the materials available in the lingua francas. Both Kiswahili and Hausa have written traditions that extend back several hundred years, and they have plenty of material in print. This material is limited, however, in terms of genre, much of it being religious or educational. There is little scientific discussion, nor is there a great variety of literary forms, especially when considered in comparison with the supralanguages. More material can be produced, of course, but it will inevitably take time, especially when writers, having been educated in the supralanguage, find that language easier to use. One answer, for the meanwhile, is to focus on translation, as Julius Nyerere did in rendering Shakespeare's Julius Caesar in Kiswahili (Mazrui, 2004: 126). Translation forces the development of the language in terms of vocabulary and makes new rhetorical structures and genres available for writers to employ in original works. It is important that such sophisticated material be developed if African languages are to be seen as appropriate media for real, grown-up, reading, and not just for the education of children.

But the real matter with the African lingua francas is political. On the one hand they face increasing competition from the supralanguages (especially English) as the latter are spread through education and through access to the global media. On the other hand, the lingua francas are all too often distrusted as being associated with particular ethnic groups whose dominance is feared by others. Both problems may be compounded by straightforward prejudice: many southern Ugandans, for instance, consider Kiswahili to be the language of thieves, and therefore they refuse to learn it (Kagaba, 2000: 30). Such attitudes are hardly justifiable, but they are nonetheless powerful, and they can only be overcome by determined and sustained official support for the lingua francas. If governments want the lingua francas to flourish as media for literacy, they cannot simply legislate their use; they must put resources behind 
them so that teachers can be trained and translators and materials producers encouraged (McGregor, 2000: 10).

Local language literacies, on the other hand, matter for somewhat different reasons. Like the lingua francas, the local languages are obviously identified as African and are equally obviously not identified with an educated elite. But most local languages have little or no tradition of literacy-some do not even have an orthography. Literacy in such languages will not, then, give access to a significant amount of material; it is important to encourage it precisely so that such material can be developed and thus to affirm the cultures with which the languages are associated. The development of local language literacies is also important for ensuring that the languages themselves survive. At present these languages may not seem threatened, being still universally spoken within their communities; but their speakers often do not maintain them if they move to the towns, and after a generation or two of education and urbanisation many of Africa's languages may be in danger of extinction. The experience of the Celtic languages, especially the relatively strong position of Welsh, suggests that widespread access to highly valued written texts may be critical to the maintenance and potential for revival of these languages (Durcakz, 1982).

The local languages have an obvious advantage as media of instruction: they are the mother tongues of their speakers and as such are the most appropriate medium for the teaching of initial literacy; and they have the additional advantage, like the lingua francas, that their orthographies maintain a good match between graphemes and phonemes. The problem is that material for literacy instruction often does not exist at all, nor are there many teachers who, having been themselves taught in the supralanguage, feel competent to teach in a local one, even if it is their mother tongue (Keshubi, 2000: 49). And both materials production and teacher training are extremely difficult because of the sheer multiplicity of the local languages: in Uganda there are more than thirty of them, in Nigeria well over 400 (Hansford, Bendor-Samuel, and Stanford, 1976, Ladefoged, Glick, and Criper, 1971). It is clearly not possible to provide a teacher training college or even a set of books for each one. The solution, it seems to me, is to get away from top-down models of teaching and learning to ones in which students themselves are the sources of information and the producers of texts. Such methods have been used successfully at elementary level in the United States (Heath, 1983: 315-42), and I myself have used them to great effect for teaching teachers in China (Parry and Su, 1998); they can undoubtedly be used in Africa, but only if the established models of instruction are subverted.

The Kitengesa Community Library is a step towards such subversion in that it provides students with direct access to books, thus reducing their dependence 
on their teachers as mediators of knowledge. On the other hand, the collection clearly reflects the problems of lingua franca and local language literacies discussed above. The local language is Luganda, and since its inception the library has maintained a policy of acquiring every Luganda book that is available. Despite this policy our stock in July 2006 included only 203 Luganda books, as against 2,496 English ones, and there were only five in Kiswahili. The last problem can be addressed: we can buy more Kiswahili books, and since few people will read them under present sociolinguistic circumstances, we will look for ones with parallel translations in English or Luganda. These may become a valuable resource if and when the government becomes serious about its policy of promoting Kiswahili at secondary level, and they will open the way for monolingual Kiswahili texts. As for Luganda books, we will continue to buy whatever we can find, but we are also encouraging students in the school to produce their own Luganda texts, which we will print out and distribute. Some may be concerned that such student-produced texts may not be in "correct" Luganda, but I don't think that such a concern for correctness should stop their production. The writing of the language is more important than its standardisation.

Different languages, then, mean different literacies. But literacies vary along other dimensions as well, according to their purposes, their genres, the technologies through which they are mediated, the social contexts in which they are practised, and many others. I cannot hope to be comprehensive here, so I will take only one more dimension into consideration, namely the literacies associated with different social contexts. Nor can I cover all the possibilities in this dimension, but I will consider those that seem to be most important at Kitengesa.

The dominant literacy, in Kitengesa as elsewhere, is undoubtedly the literacy of school. School is where most people learn to read, and most reading is done in and for school classes. So close is the association between schooling and literacy that many Ugandans use "reading" as a synonym for "studying". Yet many schools, including Kitengesa Comprehensive Secondary School, are pitifully short of books: they do not even have basic textbooks, and in those cases where textbooks are available, the range is still narrow; neither teachers nor students expect to get information from more than one book per subject (Liang, 2002, Muwanga et al., 2007). These conditions have tended to reinforce those top-down models of instruction that I mentioned earlier. As one highly experienced trainer of teachers in Uganda has said:

Most teachers assume that they "possess" their classes and adopt a teacher-centred mode of teaching, assuming the role of experts who have to perform all the time. ... Their conception of their role as 
teachers, together with their failure to understand what the reading skill entails, leads them to usurp the learners' role. During reading lessons, they take it upon themselves to read to and for the class, even when the pupils have the same text in their hands. (Izizinga, 2000: 67-68)

An important role for the Kitengesa Community Library, then, is to complement the schools by providing textbooks, making a greater variety available than is usual, and giving students opportunities to read them for themselves. This role in relation to school literacy is signified clearly by the library's proximity to Kitengesa Comprehensive Secondary School and by the fact that members of the school are entitled to free membership of the library (other library members have to pay a small annual fee). Library policy is to hold at least one complete set of textbooks for each subject at both primary and secondary levels of education, and where possible we provide alternative sets. These books are kept in the library as reference books, so that students and teachers alike must come into the building to read them. The library has thus become a place of study: of 7,262 visits paid to the building between January and October 2005, 4,279 or 59\%, were for the declared purpose of "reading books", while a further 1,262 or $17 \%$, were for "revising". Of course, visitors may have been reading other books than textbooks, but the impression that the librarians get is that textbooks are the most popular genre for in-library reading. Kitengesa Comprehensive Secondary School teachers also often give students assignments that are based on work to be done in the library (Dent and Yannotta, 2005).

But is school literacy enough? All too often it is narrowly constrained, dominated by teachers who are themselves controlled by centrally developed curricula that are enforced through the medium of exams. Students who have no other literacy available are unlikely to extend and transform the literacy they acquire in school, and once the last of their exams is over, they tend to abandon it altogether. It is vital, then, to encourage the development of literacies in association with other social contexts, and that is another important function of the library.

Studies conducted in North America and Britain (e.g. Heath, 1983, Wells, 1986) have long since demonstrated the importance of literacy as a part of family life, and Heath's work, in particular, brought out how variable family literacy can be. An important question for the Kitengesa Community Library, then, is whether and how it is contributing to literacy in the family. There is good reason to believe that it is doing so, if only because most (68\%) of the books that the library lends are borrowed by women and girls-and in the local community girls are expected to go home after school and to stay there, 
helping with household chores; thus a book borrowed by a girl is likely to be read at home. The reports that the students submitted over the first year when they were borrowing books also suggest that girls are likely to share them with more people (either by reading them aloud or by passing them on) than boys are likely to do. In the course of 1999, 87 loans were made to 15 boys and 195 to 54 girls: the girls reported that they read each book aloud to an average of 2.7 listeners, while the boys reported reading each book to only 2.1 ; likewise the girls lent each book to an average of 2.4 readers and the boys to only 2.0; the girls' listeners and readers were also more likely to be children than the boys' were, with $47 \%$ of the girls' being under fifteen, as opposed to $32 \%$ of the boys' (Parry, 2004). It seems, then, that books once borrowed, especially when borrowed by girls, get passed around and read aloud within the home. We need to know much more, however, about the circumstances and manner in which this happens, to get a full understanding of the library's contribution to family literacy.

The library seems also to be encouraging the development of literacy practices as part of interactions within peer groups and among friends. Again, such literacy practices have been documented in North America, where students often use them in opposition to the discipline imposed by the school and to the dominance of their teachers (Camitta, 1993, Gilmore, 1986; Leander, 2004). In the context of Kitengesa, peer group literacy practices do not work in opposition to the formal education system so much as in addition to it. The resident librarian reports, for example, that one of the students who helps him run the library became interested in one of the new science books that I purchased for the library in 2005. This student then recommended the book to another, who recommended it to another, who proceeded to tell a group of students from a different secondary school about it. Five of these students then came to the library to read the book and promised, in consequence, to become fully paid-up members (Field notes, 29 January 2007, 11). If such incidents occur frequently, the reading of books will become associated with friendship networks as much as, or even more than, with classroom activities, and this could be an enormously significant development in that it would undermine the teachers' monopoly of knowledge. Moreover, peer group literacy is already going beyond the school curriculum. The library has been the base for two student clubs, the Newspaper Club and the Straight Talk Club, Straight Talk being a monthly newspaper pullout that is devoted to disseminating information about HIV-AIDS. The Newspaper Club meets daily at lunch time to read articles aloud from both the English and the Luganda newspapers; the Straight Talk Club meets in single-sex groups to discuss the articles in Straight Talk and then in a combined group to resolve any language difficulties encountered. Finally, the books that get borrowed-traditional stories, modern stories, and 
the rest-are passed from one student to another within friendship networks, and the students have often been heard talking about the books.

With family literacy and peer group literacy in Kitengesa we are seeing written text-in the form of library books-being taken into existing social groups and becoming part of an already established network of oral interactions. But books can also be read privately by individuals, exposing those individuals, at least potentially, to an infinitely wider range of influences. This kind of literacy practice has often been assumed to be the norm (Howe, 1993), and the assumption has led to enormous claims for the consequences of literacy as such (Goody, 1968, Ong, 1982). The assumption and the claims have been effectively disproven in the work of Street and others, yet there is a small baby that should be preserved from the bath water: when books can be borrowed they can be read by individuals on their own, and more than one student from Kitengesa has indicated that this is an important point. As one girl wrote in a book report, the title Girls Growing Up (Nganda, 1994) was a book for "reading secretly". Nor is the potential for "secrecy" in reading important only for sex education (especially so in a society that is reserved about such matters); it has the potential, at least, for people to improve their knowledge and thus their social status. The librarian explained the process by which this can happen when describing how he held his own in conversation with the teachers in the school, who were much more qualified than him at the time, in terms of formal education levels:

We used to have tea in the staffroom there ... and ... talk about things, like ... economics, ... and then the economic teacher would talk something, then when I go back I make sure that I go and read something about that so that maybe at lunch I will also have something to say about it ...I took that advantage because I was in the library and then I would read and read and read so next time I had something ... (Field notes, 29 January 2007, 6)

Thus he acquired a considerable reputation for being knowledgeable, all on the basis of what he had read on his own in the library.

This man, it must be admitted, is exceptional: there is no doubt that for most of the people around Kitengesa, and probably many others in Africa, literacy begins and ends with school literacy. Our librarian and our library, however, have demonstrated that that does not have to be the case. The availability of books outside school, and unmediated by teachers, has opened up a space for family, peer group, and private literacies to develop, and it has gone some way-though not, I think, far enough - to encourage the development of literacy in the local language. And while school literacy will remain the one that 
matters most in terms of social status and access to employment, it will itself become far more productive and effective if supplemented and supported by these other literacies (cf. Ntuli and Pretorius, 2005). Finally, I should say that libraries are certainly not the only institutional structures through which these literacies can be encouraged and promoted. I have been most impressed by what I have learned from colleagues in South Africa about family literacy projects, local language publishing, and research in workplace literacy practices (Desmond, 2004, Land, 2005, Mashishi 2009, Prinsloo and Breier, 1996). All such projects help us to think about and work on literacy matters beyond the school, and it is important that we do so-because there are multiple literacies, and they all matter.

\section{Acknowledgement}

An earlier version of this paper was presented as the keynote address at the Reading Association of South Africa's $2^{\text {nd }}$ Annual Literacy Conference, held in Cape Town on 11-12 November, 2006. I am grateful to the organisers of the conference for inviting me to make the address, to the American Embassy in Pretoria for its support, and especially to Janet Condy and Mastin Prinsloo for their generous hospitality.

\section{References}

Baleeta, M. L. 2004. Cultural Background and Test Performance on Unseen Passages. Master's Dissertation, Makerere University, Kampala, Uganda.

Barton, D. 1994. Literacy: An Introduction to the Ecology of Written Language. Oxford: Blackwell.

Camitta, M. 1993. Vernacular writing: Varieties of literacy among Philadelphia high school students. In Cross-cultural Approaches to Literacy, B. V. Street (ed.). Cambridge: Cambridge University Press, 228-246.

Carr-Hill, R. A., Okech, A, Katahoire, A. R., Kakooza, T., Ndidde, A. N., and Oxenham, J. 2001. Adult Literacy Programmes in Uganda. Washington, DC: World Bank.

Cope, B., and Kalantzis, M. (eds). 2000. Multiliteracies: Literacy Learning and the Design of Social Futures. London: Routledge.

Dent, V. F., and Yannotta, L. 2005. A rural community library in Africa: A study of its use and users. Libri, 55: 39-55.

Desmond, S. 2004. Literacy for now and for the future: Working with parents and children. Language Matters, 35(2): 348-362.

Downing, J. A. 1979. Reading and Reasoning. New York: Springer-Verlag.

Durcakz, V. E. 1982. The Decline of the Celtic Languages: A study of linguistic and cultural conflict in Scotland, Wales, and Ireland from the Reformation to the Twentieth century. Edinburgh: John Donald.

Gilmore, P. 1986. Sub-rosa literacy: Peers, play, and ownership in literacy. In The acquisition of literacy: Ethnographic perspectives, B. B. Schieffelin and P. Gilmore (eds). Norwood, NJ: Ablex, 155-168. 
Goody, J. 1968 and Watt, I. 1963. The consequences of literacy. In Literacy in traditional societies, J. Goody (ed.). Cambridge: Cambridge University Press, 27-84

Hansford, K., Bendor-Samuel, J., and Stanford, R. 1976. An index of Nigerian Languages. Accra: Summer Institute of Linguistics.

Heath, S. B. 1983. Ways with words: Language, life, and work in communities and classrooms. Cambridge: Cambridge University Press.

Howe, N. 1993. The cultural construction of reading in Anglo-Saxon England. In The ethnography of reading, J. Boyarin (ed.). Berkeley: University of California Press.

Izizinga, R. 2000. The teaching of reading in Uganda. In Language and literacy in Uganda: Towards a Sustainable Reading Culture, K. Parry (ed.). Kampala: Fountain Publishers, 66-70.

Kagaba, P. 2000. Promoting Kiswahili in Ugandan schools: A report on progress. In Language and literacy in Uganda: Towards a sustainable reading culture, K. Parry (ed.). Kampala: Fountain Publishers, 30-33.

Keshubi, H. 2000. Teaching local languages in Primary Teachers' Colleges in Uganda. In Language and literacy in Uganda: Towards a sustainable reading culture, K. Parry (ed.). Kampala: Fountain Publishers, 46-50.

Ladefoged, P., Glick, R., and Criper, C. (eds). 1971. Language in Uganda. Nairobi: Oxford University Press.

Land, S. 2005. The Centre for Adult Education Annual Report 2003 and 2004. Pietermaritzburg: CAE, University of KwaZulu-Natal.

Leander, K. M. 2004. Literacy networks: Following the circulation of texts, bodies and discourses in the online and offline literacy practices of adolescents. Paper presented at the Series on Multimodal Discourse, February 2004, Teachers College, New York.

Liang, X. 2002. Uganda post-primary education sector report. Africa region human development working paper series, World Bank. Downloaded in May 2007 from http://www-wds. worldbank.org/external/default/main?pagePK=64193027\&piPK=64187937\&theSiteP $\mathrm{K}=523679$ \&menuPK=64187510\&searchMenuPK=64187283\&theSitePK=523679\&en tityID=000160016_20030912110459\&searchMenuPK=64187283\&theSitePK=523679

Mashishi, L. 2009. The Families Learning Together Programme: Working in a South African township. In Reading in Africa, Beyond the School, K. Parry (ed.) Kampala: Fountain Publishers, 229-244.

Matovu, G. G. 1994. Magulu and the Gorilla. Kampala: Fountain Publishers.

Mazrui, A. A., and Mazrui, A. M. 1998. The Power of Babel: Language and Governance in the African experience. Chicago: University of Chicago Press.

Mazrui, A. M. 2004. English in Africa after the Cold War. Clevedon: Multilingual Matters.

McGregor, G. P. 2000. National policy and practice in language and literature education: Some reflections from afar. In Language and literacy in Uganda: Towards a sustainable reading culture, K. Parry (ed.). Kampala: Fountain Publishers, 6-13.

Muwanga, N. K., Aguti, J. N., Ndidde, A. N., and Siminyu, S. N. 2007. Literacy Practices in Primary Schools in Uganda: Lessons for future interventions. Kampala: Fountain Publishers.

Nganda, C. N. 1994. Girls growing up. Nairobi: Paulines Publications Africa.

Ngugi wa Thiongo. 1986. Decolonising the mind: The Politics of language in African literature. London: Heinemann/J. Currey. 
Ntuli, D. and Pretorius, E. J. 2005. Laying foundations for academic language cdfompetence: The effects of storybook reading on Zulu language, literacy and discourse development. Southern African Linguistics and Applied Language Studies, 23 (1): 91-109.

Ong, W. J. 1982. Orality and literacy: The technologizing of the word. London: Methuen.

Parry, K. 1994. The test and the text: Readers in a Nigerian secondary school. In From testing to assessment: English as an international language, C. A. Hill and K. Parry (eds). London: Longman, 82-113.

Parry, K. 1999. Language and literacy in African contexts. Language matters: Studies in the languages of southern Africa, 30: 113-130.

Parry, K. 2004. Opportunities for girls: A community library project in Uganda. In Gender and English language learners, B. Norton and A. Pavlenko (eds). Alexandria, VA: TESOL Publications, 81-93.

Parry, K. 2005. Cultural differences in reading: Reading processes and the development of a reading culture. In Teaching reading in African Schools, K. Parry, S. Andema, and L. Tumusiime (eds). Kampala: Fountain Publishers, 315-334.

Parry, K. 2009. Languages, literacies, and libraries: a view from Africa. In The languages of Africa and the diaspora: Educating for language awareness, J. A. Kleifgen and G. C. Bond (eds). Clevedon: Multilingual Matters, 76-88.

Parry, K. and Su, X (eds). 1998. Culture, literacy, and learning English: Voices from the Chinese classroom. Portsmouth, NH: Heinemann.

Prinsloo, M. and Breier, M. (eds). 1996. The Social uses of litercy: Theory and practice in contemporary South Africa. Philadelphia: John Benjamins.

Rubagumya, C. M. 2009. The policy of language and literacy in Africa: The experience of Tanzania. In Reading in Africa, Beyond the school, K. Parry (ed.). Kampala: Fountain Publishers, 11-23.

Schmied, J. J. 1991. English in Africa: An introduction. London: Longman.

Street, B. V. 1984. Literacy in theory and practice. Cambridge: Cambridge University Press.

Uganda Government. 1992. Education for national integration and development: Government White Paper on implementation of the recommendation of the report of the Education Policy Review Commission. Kampala: Author.

Wells, C. G. 1986. The language experience of five-year-old children at home and at school. In The social construction of literacy, J. Cook-Gumperz (ed.). Cambridge: Cambridge University Press, 69-93. 